Article

\title{
Iron(II) Spin Crossover Complex with the 1,2,3-Triazole-Containing Linear Pentadentate Schiff-Base Ligand and the $\mathrm{MeCN}$ Monodentate Ligand
}

\author{
Tomoe Matsuyama ${ }^{1}$, Keishi Nakata ${ }^{2}$, Hiroaki Hagiwara ${ }^{1, *(1)}$ and Taro Udagawa ${ }^{3}$ \\ 1 Department of Chemistry, Faculty of Education, Gifu University, Yanagido 1-1, Gifu 501-1193, Japan; \\ v1008407@edu.gifu-u.ac.jp \\ 2 Graduate School of Education, Gifu University, Yanagido 1-1, Gifu 501-1193, Japan; \\ x1131019@edu.gifu-u.ac.jp \\ 3 Department of Chemistry and Biomolecular Science, Faculty of Engineering, Gifu University, Yanagido 1-1, \\ Gifu 501-1193, Japan; udagawa@gifu-u.ac.jp \\ * Correspondence: hagiwara@gifu-u.ac.jp; Tel.: +81-58-293-2253
}

Received: 16 May 2019; Accepted: 25 May 2019; Published: 28 May 2019

check for updates

\begin{abstract}
A mononuclear iron(II) complex bearing the linear pentadentate $\mathrm{N}_{5}$ Schiff-base ligand containing two 1,2,3-triazole moieties and the MeCN monodentate ligand, [Fe ${ }^{\mathrm{II}} \mathrm{MeCN}\left(\mathrm{L}_{3-\mathrm{Me}-3}{ }^{\mathrm{Ph}}\right)$ ] $\left(\mathrm{BPh}_{4}\right)_{2} \cdot \mathrm{MeCN} \cdot \mathrm{H}_{2} \mathrm{O}(\mathbf{1})$, have been prepared $\left(\mathrm{L}_{3-\mathrm{Me}-3}{ }^{\mathrm{Ph}}=\operatorname{bis}\left(N, N^{\prime}-1\right.\right.$-Phenyl-1H-1,2,3-triazol-4-ylmethylideneaminopropyl)methylamine). Variable-temperature magnetic susceptibility measurements revealed an incomplete one-step spin crossover (SCO) from the room-temperature low-spin (LS, $S=0$ ) state to a mixture of the LS and high-spin (HS, $S=2$ ) species at the higher temperature of around $400 \mathrm{~K}$ upon first heating, which is irreversible on the consecutive cooling mode. The magnetic modulation at around $400 \mathrm{~K}$ was induced by the crystal-to-amorphous transformation accompanied by the loss of lattice MeCN solvent, which was evident from powder X-ray diffraction (PXRD) studies and themogravimetry. The single-crystal $\mathrm{X}$-ray diffraction studies showed that the complex is in the LS state $(S=0)$ between 296 and $387 \mathrm{~K}$. In the crystal lattice, the complex-cations and $\mathrm{B}(1) \mathrm{Ph}_{4}{ }^{-}$ions are alternately connected by intermolecular $\mathrm{CH} \cdots \pi$ interactions between the methyl group of the $\mathrm{MeCN}$ ligand and phenyl groups of $\mathrm{B}(1) \mathrm{Ph}_{4}{ }^{-}$ions, forming a $1 \mathrm{D}$ chain structure. The 1D chains are further connected by P4AE (parallel fourfold aryl embrace) interactions between two neighboring complex-cations, constructing a $2 \mathrm{D}$ extended structure. $\mathrm{B}(2) \mathrm{Ph}_{4}{ }^{-}$ions and MeCN lattice solvents exist in the spaces of the 2D layer. DFT calculations verified that the 1,2,3-triazole-containing ligand $\mathrm{L}_{3-\mathrm{Me}-3}{ }^{\mathrm{Ph}}$ gives a stronger ligand field around the octahedral coordination environment of the iron(II) ion than the analogous imidazole-containing ligand $\mathrm{H}_{2} \mathrm{~L}^{2 \mathrm{Me}}$ (= bis $\left(N, N^{\prime}\right.$-2-methylimidazol-4-yl-methylideneaminopropyl)methylamine) of the known compound $\left[\mathrm{Fe}^{\mathrm{II}} \mathrm{MeCN}\left(\mathrm{H}_{2} \mathrm{~L}^{2 \mathrm{Me}}\right)\right]\left(\mathrm{BPh}_{4}\right)_{1.5} \cdot \mathrm{Cl}_{0.5} \cdot 0.5 \mathrm{MeCN}$ (2) reported by Matsumoto et al. (Nishi, K.; Fujinami, T.; Kitabayashi, A.; Matsumoto, N. Tetrameric spin crossover iron(II) complex constructed by imidazole...chloride hydrogen bonds. Inorg. Chem. Commun. 2011, 14, 1073-1076), resulting in the much higher spin transition temperature of $\mathbf{1}$ than that of 2.
\end{abstract}

Keywords: spin crossover; linear pentadentate ligand; iron(II); mononuclear; 1,2,3-triazole; crystal structure; magnetic properties; DFT calculation; intermolecular interactions; amorphous 


\section{Introduction}

Spin crossover (SCO) materials exhibiting spin state-interconversion between the high-spin (HS) and the low-spin (LS) states have attracted much attention since they have a great potential for applications in data storage, display, switching device, sensors for temperature, pressure, gas, and solvent, and also multi-modal sensing technology [1-5]. For the real-world applications, SCO compounds must fulfill demands such as a proper room temperature (RT) response, abrupt spin transition, wide thermal hysteresis, and high durability at least [6,7]. Multistep [8-11] and high-temperature (HT) [12-18] SCO complexes also provide demands for the development of multinary memories and for the investigation of the thermal stability of spin transition under extreme conditions, respectively. These properties are complicatedly affected by the ligand field strength of each SCO molecule and cooperativity between SCO metal sites. Generally, the important factors are the ligand backbone, molecular structure of each SCO molecule, accompanying components (counter ions and lattice solvents), crystal packing, and cooperative interactions through intermolecular interactions [19,20] and/or bridging ligands [21]. The most essential need, namely RT operation, is achievable by controlling the spin transition temperature $\left(T_{1 / 2}\right)$. Thus, the various molecular design and modifications have been reported for the precise tuning of $T_{1 / 2}$ [22-29].

Octahedral metal complexes with pentadentate ligand are of interest since their ligand field strength can be systematically controlled by modifying the additional monodentate ligand in line with the spectrochemical series [30-32], and such a characteristic is useful not only for exhibiting SCO but also for the possible tuning of $T_{1 / 2}$. These complexes are also beneficial for the construction of polynuclear materials such as di [33-42], tri [43], tetra [44], penta [45], hepta [46-48], nona [48] and dodecanuclear [49] complexes by using bridging ligands instead of monodentate ligands for exhibiting multi-step spin transition. In the pentadentate ligand system, although iron(III) SCO compounds are well known [50-57], iron(II) spin transition systems are quite rare [58,59]. One of the reasons for this is the difficulty of the crystallization of iron(II) complexes with pentadentate ligand, as pointed out by Matsumoto et al. [60]. To the best of our knowledge, only one SCO iron(II) complex with linear pentadentate ligand, which shows the gradual and partial SCO below RT, has been reported so far [59]. So, our ongoing interest for exploring RT and HT SCO systems by using 1,2,3-triazole-containing multidentate Schiff-base ligands spontaneously extends to the next project for the synthesis of a SCO iron(II) complex bearing linear pentadentate ligand, which is missing in our tridentate to hexadentate ligand family $[15,18,26,61-63]$.

In this study, we have synthesized an iron(II) complex with $\mathrm{N}_{6}$ donor atoms from the 1,2,3-triazole-containing pentadentate ligand $\mathrm{L}_{3-\mathrm{Me}-3} \mathrm{Ph}$ and the monodentate neutral ligand $\mathrm{MeCN}$, $\left[\mathrm{Fe}^{\mathrm{II}} \mathrm{MeCN}\left(\mathrm{L}_{3-\mathrm{Me}-3}{ }^{\mathrm{Ph}}\right)\right]\left(\mathrm{BPh}_{4}\right)_{2} \cdot \mathrm{MeCN} \cdot \mathrm{H}_{2} \mathrm{O}(1)\left(\mathrm{L}_{3-\mathrm{Me}-3}{ }^{\mathrm{Ph}}=\right.$ bis $\left(\mathrm{N}_{,} \mathrm{N}^{\prime}-1-\mathrm{Phenyl}-1 \mathrm{H}-1,2,3-\right.$ triazol-4-ylmethylideneaminopropyl)methylamine, Scheme 1) inspired by the above-mentioned SCO iron(II) complex having imidazole-containing linear pentadentate ligand, [ $\mathrm{Fe}^{\mathrm{II}} \mathrm{MeCN}\left(\mathrm{H}_{2} \mathrm{~L}^{2 \mathrm{Me}}\right)$ ] $\left(\mathrm{BPh}_{4}\right)_{1.5} \cdot \mathrm{Cl}_{0.5} \cdot 0.5 \mathrm{MeCN}(2)\left(\mathrm{H}_{2} \mathrm{~L}^{2 \mathrm{Me}}=\operatorname{bis}\left(N, N^{\prime}-2\right.\right.$-methylimidazol-4-yl-methylideneaminopropyl) methylamine) [59]. We report here the synthesis, crystal structures, and thermal and magnetic properties of $\mathbf{1}$ with the first theoretical comparison of the 1,2,3-triazole- and imidazole-containing multidentate ligand system.

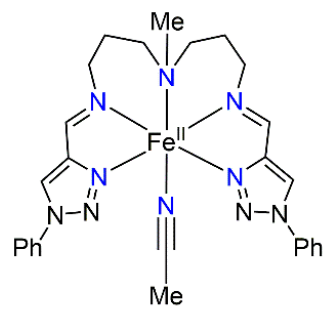

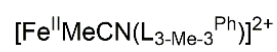

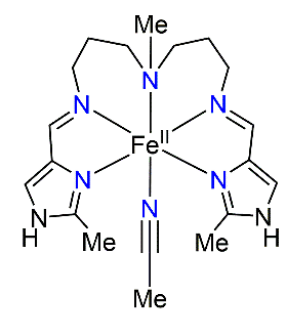

$\left[\mathrm{Fe} " \mathrm{MeCN}\left(\mathrm{H}_{2} \mathrm{~L}^{2 \mathrm{Me}}\right)\right]^{2+}$

Scheme 1. Schematic structures of $\left[\mathrm{Fe}^{\mathrm{II}} \mathrm{MeCN}\left(\mathrm{L}_{3-\mathrm{Me}-3}{ }^{\mathrm{Ph}}\right)\right]^{2+}$ and $\left[\mathrm{Fe}^{\mathrm{II}} \mathrm{MeCN}\left(\mathrm{H}_{2} \mathrm{~L}^{2 \mathrm{Me}}\right)\right]^{2+}$. 


\section{Materials and Methods}

\subsection{Synthesis of $F e^{I I}$ Complex}

\subsubsection{General}

All reagents and solvents were purchased from commercial sources and used for the syntheses without further purification. The 1-phenyl-1H-1,2,3-triazole-4-carbaldehyde was synthesized according to the reported procedures [62,64-66]. Complexation and crystallization of 1 were performed under nitrogen atmosphere using standard Schlenk techniques. Other synthetic procedures were carried out in air.

2.1.2. Synthesis of the Linear Pentadentate $\mathrm{N}_{5}$ Ligand $\mathrm{L}_{3-\mathrm{Me}-3} \mathrm{Ph}=$ bis(N,N'-1-Phenyl-1H-1,2,3-triazol-4-yl-methylideneaminopropyl)methylamine

The ligand $\mathrm{L}_{3-\mathrm{Me}-3} \mathrm{Ph}$ was prepared by mixing 3,3'-diamino- $\mathrm{N}$-methyldipropylamine and 1-phenyl-1H-1,2,3-triazole-4-carbaldehyde with a 1:2 molar ratio in MeCN. The ligand solution thus prepared was used for the synthesis of $\mathrm{Fe}^{\mathrm{II}}$ complex without further purification and isolation.

\subsubsection{Preparation of $\left[\mathrm{Fe}^{\mathrm{II}} \mathrm{MeCN}\left(\mathrm{L}_{3-\mathrm{Me}-3}{ }^{\mathrm{Ph}}\right)\right]\left(\mathrm{BPh}_{4}\right)_{2} \cdot \mathrm{MeCN} \cdot \mathrm{H}_{2} \mathrm{O}(\mathbf{1})$}

3,3'-diamino- $N$-methyldipropylamine $(0.109 \mathrm{~g}, 0.75 \mathrm{mmol})$ in $\mathrm{MeCN}(3 \mathrm{~mL})$ was added to a solution of 1-phenyl-1H-1,2,3-triazole-4-carbaldehyde $(0.260 \mathrm{~g}, 1.5 \mathrm{mmol})$ in $\mathrm{MeCN}$ (7.5 mL). The resulting pale-yellow solution was stirred at RT for $1 \mathrm{~h}$. A solution of $\mathrm{NaBPh}_{4}(0.513 \mathrm{~g}, 1.5 \mathrm{mmol}) \mathrm{in} \mathrm{MeOH}$ $(4 \mathrm{~mL})$ was added to a solution of $\mathrm{Fe}^{\mathrm{II}} \mathrm{Cl}_{2} \cdot 4 \mathrm{H}_{2} \mathrm{O}(0.149 \mathrm{~g}, 0.75 \mathrm{mmol})$ in $\mathrm{MeOH}(4 \mathrm{~mL})$, and the resulting pale-yellow solution was stirred at RT for $5 \mathrm{~min}$. Both reaction mixtures were filtered, and they were mixed under nitrogen atmosphere. The resulting mixture was allowed to stand for a week in a fridge, during which time the precipitated dark red-brown prismatic crystals were collected by suction filtration. Yield: $0.203 \mathrm{~g}(21 \%)$. Anal. Calcd for $\left[\mathrm{Fe}^{\mathrm{II}} \mathrm{MeCN}\left(\mathrm{L}_{3-\mathrm{Me}-3}{ }^{\mathrm{Ph}}\right)\right]\left(\mathrm{BPh}_{4}\right)_{2} \cdot \mathrm{MeCN} \cdot \mathrm{H}_{2} \mathrm{O}$ (1) $=\mathrm{C}_{77} \mathrm{H}_{77} \mathrm{~B}_{2} \mathrm{FeN}_{11} \mathrm{O}: \mathrm{C}, 73.99 ; \mathrm{H}, 6.21 ; \mathrm{N}, 12.33$. Found: $\mathrm{C}, 73.78 ; \mathrm{H}, 6.03 ; \mathrm{N}, 12.03 \%$. IR $(\mathrm{KBr}): v_{\mathrm{C} \equiv \mathrm{N}}$ $2271,2251, v_{\mathrm{C}=\mathrm{N}} 1616,1593, v_{\mathrm{BPh} 4} 734,704 \mathrm{~cm}^{-1}$. A weight loss of $3.4 \%$ corresponding to the MeCN $(3.3 \%)$ and a subsequent $1.2 \%$ loss of water $(1.4 \%)$ were observed at 408 and $444 \mathrm{~K}$, respectively, by TG measurement (Figure 1).

\subsection{Physical Measurements}

Elemental C, H, and $\mathrm{N}$ analyses were performed on a J-Science Lab (Kyoto, Japan) MICRO CORDER JM-10. Infrared (IR) spectra were recorded at RT using a JASCO (Tokyo, Japan) FT/IR 460Plus spectrophotometer with the samples prepared as KBr disks. Thermogravimetric (TG) data was collected on a Rigaku (Tokyo, Japan) Thermo plus EVO2 TG-DTA8122 instrument in the temperature range of 19-359 ${ }^{\circ} \mathrm{C}(292-632 \mathrm{~K})$ at a sweep rate of $10 \mathrm{~K} \mathrm{~min}^{-1}$ under a nitrogen atmosphere $\left(200 \mathrm{~mL} \mathrm{~min}^{-1}\right)$. Real-time sample images during TG analysis were recorded under an optional direct monitoring system of the TG-DTA instrument. Magnetic susceptibilities were measured in the temperature range of $5-400 \mathrm{~K}$ at a sweep rate of $2 \mathrm{~K} \mathrm{~min}^{-1}$ under an applied magnetic field of $1 \mathrm{~T}$ using a Quantum Design (San Diego, CA, USA) MPMS-XL7 SQUID magnetometer. The sample was wrapped in an aluminum foil and was then inserted into a quartz glass tube with a small amount of glass wool filler. Corrections for diamagnetism of the sample were made using Pascal's constants [67,68]. A background correction for the sample holder was also applied. Powder X-ray diffraction (PXRD) patterns were recorded at RT on a portion of polycrystalline powders placed on a non-reflecting silicon plate, using a Rigaku MiniFlex600 diffractometer with $\mathrm{Cu} \mathrm{K} \alpha$ radiation $(\lambda=1.5418 \AA)$ operated at $0.4 \mathrm{~kW}$ power $(40 \mathrm{kV}, 10 \mathrm{~mA})$. 


\subsection{Crystallographic Data Collection and Structure Analyses}

X-ray diffraction data were collected by a Rigaku (Tokyo, Japan) AFC7R Mercury CCD diffractometer using graphite monochromated Mo K $\alpha$ radiation $(\lambda=0.71075 \AA)$ operated at $5 \mathrm{~kW}$ power $(50 \mathrm{kV}, 100 \mathrm{~mA})$. A single crystal was mounted on a glass fiber and the diffraction data were collected at $296 \mathrm{~K}$. Following the measurement at $296 \mathrm{~K}$, the crystal was warmed and the subsequent measurements were performed at 350, 375, 387, and $400 \mathrm{~K}$. The temperature of the crystal was maintained at the selected value by means of a Rigaku cooling device with nitrogen flow to within an accuracy of $\pm 2 \mathrm{~K}$. Data reductions and empirical absorption correction using spherical harmonics, implemented in a SCALE3 ABSPACK scaling algorithm (multi-scan method) [69] were performed using the CrysAlis ${ }^{\text {Pro }}$ software package (version 1.171.39.46) [70]. The structures were solved by the direct method using SHELXT [71] and refined on $F^{2}$ data using the full-matrix least-squares algorithm using SHELXL [72], both of which were implemented in the program OLEX2 (version 1.2.10) [73] with anisotropic displacement parameters for all non-hydrogen atoms. Hydrogen atoms were placed in calculated positions with idealized geometries and refined by using a riding model and isotropic displacement parameters. The continuous shape measures (CShMs) of the $\mathrm{Fe}^{\mathrm{II}}$ centers relative to the ideal octahedron, $\mathrm{S}(\mathrm{Oh})$ was calculated by the program SHAPE 2.1 [74]. The octahedral volumes of the $\mathrm{Fe} \mathrm{e}^{\mathrm{II}}$ centers were calculated using OLEX2 [73]. CCDC 1911292-1911295 contains the supplementary crystallographic data for this paper. These data can be obtained free of charge via http://www.ccdc.cam.ac.uk/conts/retrieving.html or from the CCDC (12 Union Road, Cambridge CB2 1EZ, UK; Fax: +44 1223 336033; E-mail: deposit@ccdc.cam.ac.uk).

\subsection{Computational Details}

In the present study, electronic energy was evaluated by (U)M06L [75] DFT method with a combination of 6-311G(d) electronic basis set (for all atoms except for Fe) and LANL2DZ pseudo potential (for $\mathrm{Fe}$ ) in gas phase. The M06-L functional is a local functional (i.e., 0\% Hartree-Fock exchange) and is known as one of the good exchange-correlation density functionals for transition metal chemistry. The single crystal X-ray crystallography structures were used as the initial geometries for DFT geometry optimization. We confirmed that all DFT optimized structures have no imaginary frequencies. All calculations were performed with the aid of the GAUSSIAN09 program package [76].

\section{Results and Discussion}

\subsection{Synthesis and Characterization}

The linear pentadentate $\mathrm{N}_{5}$ ligand $\mathrm{L}_{3-\mathrm{Me}-3}{ }^{\mathrm{Ph}}$ was prepared by the condensation reaction of 1-phenyl-1H-1,2,3-triazole-4-carbaldehyde and 3,3'-diamino- $N$-methyldipropylamine with a 2:1 molar ratio in $\mathrm{MeCN}$. The iron(II) complex 1 was prepared by mixing the ligand solution in $\mathrm{MeCN}$, methanolic solutions of $\mathrm{FeCl}_{2} \cdot 4 \mathrm{H}_{2} \mathrm{O}$, and $\mathrm{NaBPh}_{4}$ with a 1:1:2 molar ratio under an inert nitrogen atmosphere at ambient temperature. Dark red-brown prismatic crystals were precipitated in a week in a fridge, which are stable in the air with no efflorescence. The chemical formula of $\left[\mathrm{Fe}^{\mathrm{II}} \mathrm{MeCN}\left(\mathrm{L}_{3-\mathrm{Me}-3}{ }^{\mathrm{Ph}}\right)\right]\left(\mathrm{BPh}_{4}\right)_{2} \cdot \mathrm{MeCN} \cdot \mathrm{H}_{2} \mathrm{O}$ was confirmed by the elemental analysis and thermogravimetry (TG; Figure 1). As shown in Figure 1, when the powdery sample was heated from $19^{\circ} \mathrm{C}(292 \mathrm{~K})$ at a sweep rate of $10^{\circ} \mathrm{C} \mathrm{min}^{-1}$ under a nitrogen atmosphere $\left(200 \mathrm{~mL} \mathrm{~min}{ }^{-1}\right)$, the sample weight decreased gradually and a $3.4 \%$ weight loss was observed at $135^{\circ} \mathrm{C}(408 \mathrm{~K})$, which corresponds to the calculated weight percentage of one $\mathrm{MeCN}$ molecule per $\left[\mathrm{Fe}^{\mathrm{II}} \mathrm{MeCN}\left(\mathrm{L}_{3}-\mathrm{Me}-3{ }^{\mathrm{Ph}}\right)\right]\left(\mathrm{BPh}_{4}\right)_{2} \cdot \mathrm{MeCN} \cdot \mathrm{H}_{2} \mathrm{O}$ (3.3\%). Above this temperature, an additional gradual weight loss of $1.2 \%$, corresponding to one $\mathrm{H}_{2} \mathrm{O}$ molecule $(1.4 \%)$ was detected at $171{ }^{\circ} \mathrm{C}(444 \mathrm{~K})$. Finally, above $171{ }^{\circ} \mathrm{C}(444 \mathrm{~K})$, the weight loss became more and more abrupt. During the TG measurement, the real-time sample images were also recorded (Figure 1). Initial orange-brown color of the grinding samples at $20^{\circ} \mathrm{C}(293 \mathrm{~K})$ was retained until ca. $124{ }^{\circ} \mathrm{C}$ (397 K) upon heating, and then slightly darkened around $125^{\circ} \mathrm{C}$ (398 K). Upon further increasing the temperature, the samples were gradually shrinking from ca. $127^{\circ} \mathrm{C}(400 \mathrm{~K})$ with 
darkening, and were then melting from ca. $137^{\circ} \mathrm{C}(410 \mathrm{~K})$, and finally melted over ca. $147^{\circ} \mathrm{C}(420 \mathrm{~K})$. These changes agree with two broad endothermic peaks detected in the DTA curve. These observations and corresponding TG/DTA profiles indicated that the compound 1 showed some sort of structural modification at around $127^{\circ} \mathrm{C}(400 \mathrm{~K})$ associated with the loss of the MeCN lattice solvent, and further heating above this temperature caused melting. Thus, the magnetic susceptibilities described later were measured below $400 \mathrm{~K}$. The PXRD pattern at RT showed no apparent extra reflections compared to the simulated pattern from the structure of single-crystal X-ray diffraction analysis at $296 \mathrm{~K}$, ensuring the phase purity of $\mathbf{1}$ (Figure S1). The IR spectrum of $\mathbf{1}$ showed characteristic bands at ca. 1616 and $1593 \mathrm{~cm}^{-1}$, corresponding to the $\mathrm{C}=\mathrm{N}$ stretching vibration of the coordinated Schiff-base ligand, ca. 734 and $704 \mathrm{~cm}^{-1}$, corresponding to the $\mathrm{BPh}_{4}{ }^{-}$ion, and ca. 2271 and $2251 \mathrm{~cm}^{-1}$, corresponding to the $\mathrm{C} \equiv \mathrm{N}$ stretching vibration of the MeCN molecules (Figure S2) [53,77].

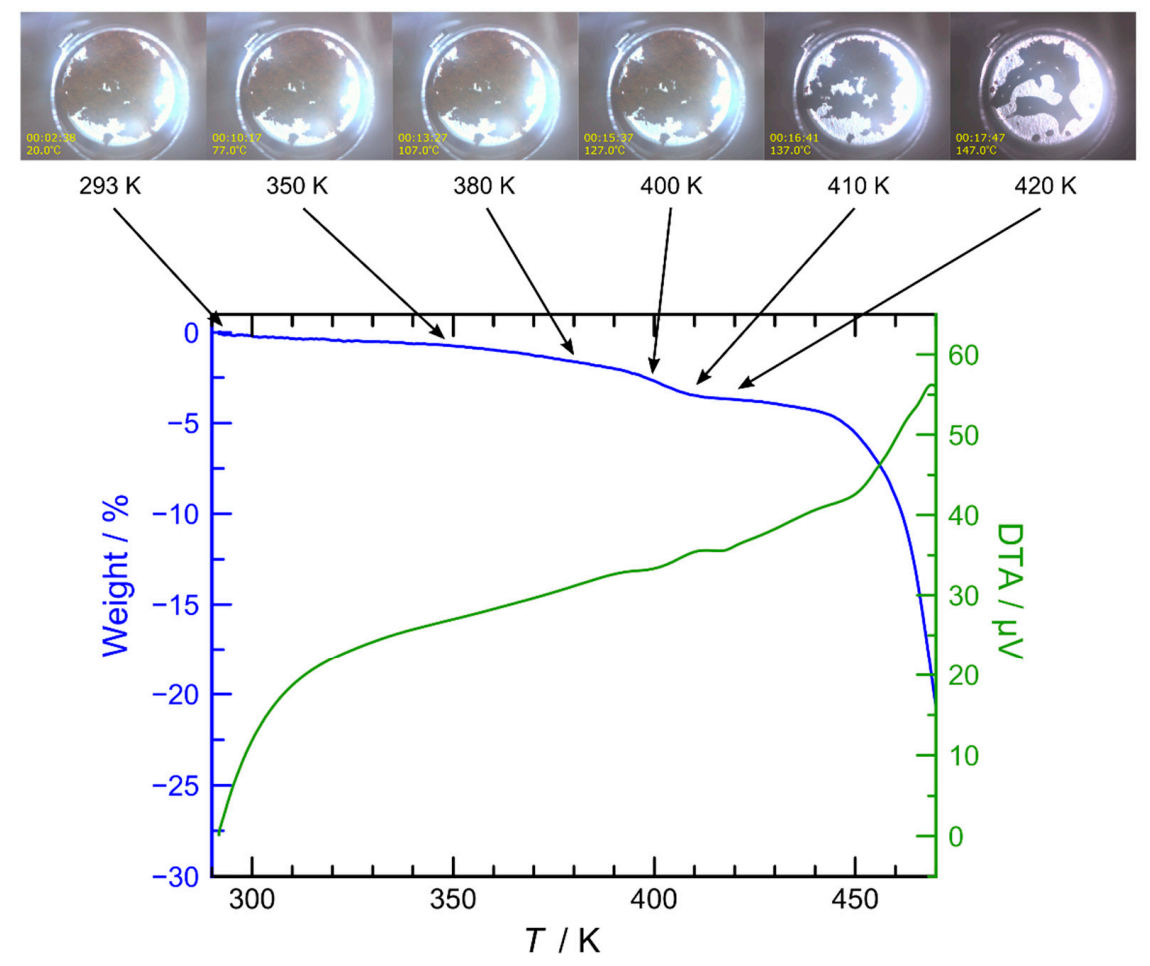

Figure 1. TG/DTA curve of 1 with the selected real-time sample images (from 293 to $420 \mathrm{~K}$ ) during the TG measurement.

\subsection{Magnetic Properties}

The magnetic susceptibilities of 1 were measured between 5 to $400 \mathrm{~K}$ at a sweep rate of $2 \mathrm{~K} \mathrm{~min}^{-1}$ under an applied magnetic field of $1 \mathrm{~T}$ using a MPMS-XL7 SQUID magnetometer (Quantum Design, San Diego, CA, USA). The $\chi_{\mathrm{M}} T$ vs. $T$ plots are shown in Figure 2, where $\chi_{\mathrm{M}}$ is the molar magnetic susceptibility and $T$ is the absolute temperature. On first cooling, the $\chi_{\mathrm{M}} T$ value of 1 is $0.2 \mathrm{~cm}^{3} \mathrm{~K} \mathrm{~mol}^{-1}$ at $300 \mathrm{~K}$ and decreases moderately to reach $0.0 \mathrm{~cm}^{3} \mathrm{~K} \mathrm{~mol}^{-1}$ at $5 \mathrm{~K}$, indicating that 1 is a $\mathrm{LS} \mathrm{Fe}^{\mathrm{II}}(S=0)$ complex. On subsequent heating, the $\chi_{\mathrm{M}} T$ value increases slightly from $0.0 \mathrm{~cm}^{3} \mathrm{~K} \mathrm{~mol}^{-1}$ at $5 \mathrm{~K}$ to ca. $0.5 \mathrm{~cm}^{3} \mathrm{~K} \mathrm{~mol}^{-1}$ at $389 \mathrm{~K}$, and then increases abruptly to reach ca. $2.2 \mathrm{~cm}^{3} \mathrm{~K} \mathrm{~mol}^{-1}$ at $400 \mathrm{~K}$. When the temperature is held at $400 \mathrm{~K}$ for $30 \mathrm{~min}$, the $\chi_{\mathrm{M}} T$ value further increases to reach $2.7 \mathrm{~cm}^{3} \mathrm{~K} \mathrm{~mol}^{-1}$ as a saturated value, indicating that ca. $90 \%$ of LS species show spin transition to the HS state. On further cooling, the $\chi_{\mathrm{M}} T$ value decreases gradually from $2.7 \mathrm{~cm}^{3} \mathrm{~K} \mathrm{~mol}^{-1}$ at $400 \mathrm{~K}$ to $2.4 \mathrm{~cm}^{3} \mathrm{~K} \mathrm{~mol}^{-1}$ at $374 \mathrm{~K}$, then decreases more smoothly to $1.6 \mathrm{~cm}^{3} \mathrm{~K} \mathrm{~mol}^{-1}$ at $20 \mathrm{~K}$, and finally decreases abruptly to ca. $1.1 \mathrm{~cm}^{3}$ $\mathrm{K} \mathrm{mol}^{-1}$ at $5 \mathrm{~K}$, revealing the coexistence of HS and LS species in the whole temperature region after the first heating. The decreasing of the $\chi_{\mathrm{M}} T$ value below $20 \mathrm{~K}$ is due to the zero-field splitting of the HS Fe ${ }^{\mathrm{II}}$ complex. 
To prove the structural modulation before and after the initial spin transition upon first heating, we took PXRD data for $\mathbf{1}$ after SQUID measurements (Figure S1). As clearly apparent from Figure S1, the crystalline phase of $\mathbf{1}$ was converted to an amorphous form after SQUID measurements. The IR spectrum for this amorphous sample was also measured (Figure S2), and the spectrum showed the additional characteristic band at ca. $1637 \mathrm{~cm}^{-1}$, corresponding to the $\mathrm{C}=\mathrm{N}$ stretching vibration of the coordinated Schiff-base ligand of the HS complex [26,62]. This result indicated the existence of both HS (albeit being not fully characterized) and LS species in the amorphous phase at RT, and was consistent with the magnetic data in the second cycle. On the other hand, the characteristic bands of the $\mathrm{C} \equiv \mathrm{N}$ stretching vibration of $\mathrm{MeCN}\left(2271\right.$ and $2251 \mathrm{~cm}^{-1}$ ) were weakened (but not perfectly disappeared) due mainly to the loss of the lattice $\mathrm{MeCN}$ solvent molecule. To sum it all up, these results demonstrate that the irreversible spin conversion at around $400 \mathrm{~K}$ in the first heating process is related to the crystal-to-amorphous transformation associated with the loss of lattice MeCN solvent. Desolvation effects are reported in a variety of SCO systems in both positive (occurrence of abrupt and/or hysteretic spin transition) and negative (disappearance of SCO) ways [78-84] but a concomitant crystal-to-amorphous transformation is rarely observed [85].

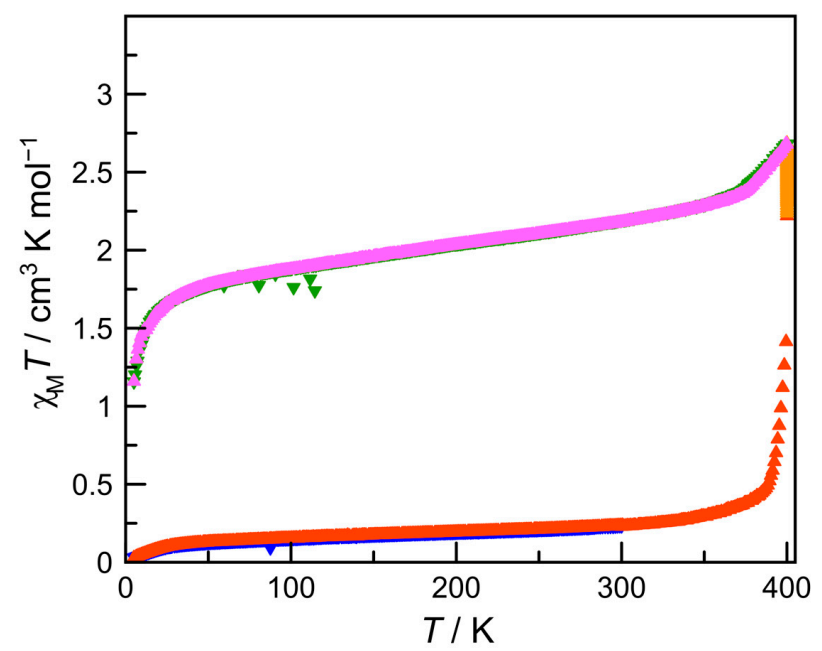

Figure 2. Temperature dependence of the $\chi_{\mathrm{M}} T$ product for 1 at a sweep rate of $2 \mathrm{~K} \mathrm{~min}^{-1}$. The sample was cooled from 300 to $5 \mathrm{~K}$ (blue inverted triangles) and then warmed from 5 to $400 \mathrm{~K}$ (red triangles) in the first cycle, and the temperature was held at $400 \mathrm{~K}$ for $30 \mathrm{~min}$ (orange triangles), and then the sample was cooled from 400 to $5 \mathrm{~K}$ (green inverted triangles) and then warmed from 5 to $400 \mathrm{~K}$ (magenta triangles) in the second cycle.

\subsection{Crystal Structures}

Single-crystal X-ray diffraction analyses were performed for 1 at 296, 350, 375, and 387 K. Structure determination at higher temperature, i.e., $400 \mathrm{~K}$ was unsuccessful since the single crystal became amorphous during the measurement. Table 1 summarizes the crystallographic data and Table 2 lists the relevant coordination bond lengths, angles, and additional structural parameters, such as $\Sigma$ [86], $\Theta$ [87], S(Oh) [74], and octahedral volume. Since the crystal structures at the four temperatures are quite similar except for the subtle expansion of the cell volume and the $\mathrm{FeN}_{6}$ coordination sphere from 296 to $387 \mathrm{~K}$, we discuss below the structure at $296 \mathrm{~K}$ as a representative. The crystallographic unique unit consists of one complex-cation $\left[\mathrm{Fe}^{\mathrm{II}} \mathrm{MeCN}\left(\mathrm{L}_{3-\mathrm{Me}-3}{ }^{\mathrm{Ph}}\right)\right]^{2+}$, two $\mathrm{BPh}_{4}{ }^{-}$ions, and one $\mathrm{MeCN}$ molecule as the lattice solvent, which is disordered at two positions. The one $\mathrm{H}_{2} \mathrm{O}$ molecule in each $\left[\mathrm{Fe}^{\mathrm{II}} \mathrm{MeCN}\left(\mathrm{L}_{3}-\mathrm{Me}-3{ }^{\mathrm{Ph}}\right)\right]\left(\mathrm{BPh}_{4}\right)_{2}$ unit characterized by elemental analysis and TG measurement could not be found, while the Platon analysis [88] indicates that there are some voids which can involve water molecules.

Figure 3 shows the molecular structure of the complex-cation $\left[\mathrm{Fe}^{\mathrm{II}} \mathrm{MeCN}\left(\mathrm{L}_{3-\mathrm{Me}-3}{ }^{\mathrm{Ph}}\right)\right]^{2+}$ at $296 \mathrm{~K}$, in which the $\mathrm{Fe}^{\mathrm{II}}$ ion is coordinated by the $\mathrm{N}_{5}$ donor atoms of the linear pentadentate Schiff-base 
ligand $\mathrm{L}_{3-\mathrm{Me}-3} \mathrm{Ph}$ and the nitrogen atom of the MeCN monodentate ligand to give an octahedral coordination environment. Two terminal triazole moieties take cis-positions, and one of two triazole moieties and the $\mathrm{MeCN}$ ligand at the sixth coordination position coordinate to the central $\mathrm{Fe}^{\mathrm{II}}$ ion from opposite directions. This coordination mode is same as that of the related imidazole-containing complex [59]. The bent angle of Fe-N10-C26 at Fe-NCMe is 172.2(1) ${ }^{\circ}$. The Fe-N lengths are in the range of 1.9580(13)-2.0901(13) $\AA$, and the average Fe-N distance is $1.988 \AA$, typical for a LS Fe ${ }^{I I}$ complex with $\mathrm{N}_{6}$ donors. It is noteworthy that the coordination bond length of $\mathrm{Fe}-\mathrm{N}$ (amine) is longer than those of other $\mathrm{Fe}-\mathrm{N}$ distances. In addition to the average $\mathrm{Fe}-\mathrm{N}$ distance, the degree of both angular and trigonal distortion, i.e., $\Sigma$ and $\Theta$, and $\mathrm{S}(\mathrm{Oh})$ (Table 2) are lower than those of related imidazole-containing complex 2 (Average Fe-N distance, $\Sigma, \Theta$, and $\mathrm{S}(\mathrm{Oh}$ ) at $296 \mathrm{~K}$ are $=2.085 \AA$, 79.7, 121.0, 1.004 for Fe1 site, and $2.155 \AA$, 89.1, 168.2, 1.541 for Fe2 site, respectively) [59]. These are consistent since the both the Fe1 and the Fe 2 site of 2 at $296 \mathrm{~K}$ are mixtures of HS and LS species.

Figure 4 shows the selected intermolecular interactions of $\mathbf{1}$ at $296 \mathrm{~K}$. Firstly, the MeCN ligand of the complex-cation is surrounded by four nearest phenyl rings of two $\mathrm{B}(1) \mathrm{Ph}_{4}{ }^{-}$ions via $\mathrm{CH} \cdots \pi$ interactions between the methyl group of the MeCN ligand and phenyl groups of $\mathrm{B}(1) \mathrm{Ph}_{4}{ }^{-}$ions with the $\mathrm{C} 27(\mathrm{Me})$ to centroid $(\mathrm{Ph})$ distances being in the range of 3.567-3.788 А. Since the three hydrogen atoms of the methyl group of the MeCN can form only three $\mathrm{CH} \cdots \pi$ interactions, the four $\mathrm{CH} \cdots \pi$ interactions of each $\mathrm{MeCN}$ indicated in Figure 4 are averaged as one. Secondly, two neighboring complex-cations are connected by a P4AE (parallel fourfold aryl embrace) interaction $[28,89]$, forming a dimeric structure with the $\mathrm{C} 23(\mathrm{Ph})$ to centroid (triazole) distance of $\mathrm{CH} \cdots \pi$ and centroid $(\mathrm{Ph})$ to centroid $(\mathrm{Ph})$ distance of $\pi-\pi$ interactions are 3.690 and $3.663 \AA$, respectively. As a result, a 1D chain structure is constructed by alternately interacted complex-cations and $\mathrm{B}(1) \mathrm{Ph}_{4}{ }^{-}$ions via $\mathrm{CH} \cdots \pi$ interactions (longitudinal direction in Figure 5), and further connections of the 1D chains through P4AE interactions (transverse direction in Figure 5) form a 2D extended layer structure. The remaining $\mathrm{B}(2) \mathrm{Ph}_{4}{ }^{-}$ions and $\mathrm{MeCN}$ lattice solvents exist in the spaces of the 2D layer with the intermolecular $\mathrm{CH} \cdots \mathrm{N}$ interaction $(\mathrm{C} 61 \cdots \mathrm{N} 11=3.486 \AA$ ). Finally, there are additional $\mathrm{CH} \cdots \pi$ interactions between the layers, resulting in the construction of a 3D supramolecular network in the whole crystal lattice. This molecular assembly is quite different from the tetrameric assembly through four intermolecular $\mathrm{NH} \cdots \mathrm{Cl}$ interactions of 2 [59]. Therefore, this difference of molecular assembly is presumably responsible for the emergence of different SCO profiles between $\mathbf{1}$ and $\mathbf{2}$.

Table 1. X-ray crystallographic data for $\mathbf{1}$

\begin{tabular}{|c|c|c|c|c|}
\hline Temperature/K & 296 & 350 & 375 & 387 \\
\hline Formula & \multicolumn{4}{|c|}{$\mathrm{C}_{77} \mathrm{H}_{75} \mathrm{~B}_{2} \mathrm{FeN}_{11}$} \\
\hline Formula weight & \multicolumn{4}{|c|}{1231.95} \\
\hline Crystal system & \multicolumn{4}{|c|}{ monoclinic } \\
\hline Space group & \multicolumn{4}{|c|}{$P 2_{1} / n$ (No.14) } \\
\hline$a / \AA$ & $11.3072(2)$ & $11.3443(2)$ & $11.3962(3)$ & $11.4005(2)$ \\
\hline$b / \AA$ & $41.0958(8)$ & $41.2866(9)$ & $41.3406(12)$ & $41.3938(10)$ \\
\hline$c / \AA$ & $14.4788(4)$ & $14.4825(4)$ & $14.4308(5)$ & $14.4297(4)$ \\
\hline$\beta /$ deg & $92.977(2)$ & $92.796(2)$ & $92.513(3)$ & $92.473(2)$ \\
\hline$V / \AA^{3}$ & $6718.9(3)$ & 6775.1(3) & $6792.2(4)$ & $6803.2(3)$ \\
\hline$Z$ & 4 & 4 & 4 & 4 \\
\hline$d_{\text {calcd. }} / \mathrm{g} \mathrm{cm}^{-3}$ & 1.218 & 1.208 & 1.205 & 1.203 \\
\hline$\mu(\operatorname{Mo~K} \alpha) / \mathrm{mm}^{-1}$ & 0.277 & 0.275 & 0.274 & 0.273 \\
\hline$R_{1}^{\text {a }}(\mathrm{I}>2 \operatorname{sigma}(\mathrm{I}))$ & 0.0458 & 0.0500 & 0.0779 & 0.0601 \\
\hline$w R_{2}{ }^{b}(\mathrm{I}>2 \operatorname{sigma}(\mathrm{I}))$ & 0.1062 & 0.1176 & 0.1944 & 0.1511 \\
\hline$R_{1}$ a (all data) & 0.0678 & 0.0826 & 0.1220 & 0.1030 \\
\hline$w R_{2}{ }^{b}$ (all data) & 0.1161 & 0.1328 & 0.2177 & 0.1738 \\
\hline$S$ & 1.029 & 1.022 & 1.065 & 1.022 \\
\hline CCDC number & 1911292 & 1911293 & 1911294 & 1911295 \\
\hline
\end{tabular}


Table 2. Relevant coordination bond lengths $(\AA)$, angles $\left(^{\circ}\right)$ and structural parameters for $1 . \Sigma[86]$ and $\Theta$ [87] are angular indices characteristic for the spin state of the complex. S(Oh) is the continuous shape measures (CShMs) of the $\mathrm{Fe}^{\mathrm{II}}$ centers relative to the ideal octahedron [74].

\begin{tabular}{ccccc}
\hline Temperature/K & $\mathbf{2 9 6}$ & $\mathbf{3 5 0}$ & $\mathbf{3 7 5}$ & $\mathbf{3 8 7}$ \\
\hline Fe1-N3 & $1.9770(13)$ & $1.9788(15)$ & $1.989(3)$ & $1.986(2)$ \\
Fe1-N4 & $1.9955(11)$ & $1.9976(13)$ & $2.004(2)$ & $1.9985(18)$ \\
Fe1-N5 & $2.0901(13)$ & $2.0918(15)$ & $2.088(3)$ & $2.093(2)$ \\
Fe1-N6 & $1.9477(12)$ & $1.9494(14)$ & $1.947(2)$ & $1.9533(19)$ \\
Fe1-N7 & $1.9577(12)$ & $1.9619(14)$ & $1.966(2)$ & $1.9683(17)$ \\
Fe1-N10 & $1.9580(13)$ & $1.9599(15)$ & $1.961(3)$ & $1.967(2)$ \\
Average Fe-N & 1.988 & 1.990 & 1.993 & 1.994 \\
N3-Fe1-N4 & $80.25(5)$ & $80.04(6)$ & $79.94(10)$ & $79.85(8)$ \\
N3-Fe1-N5 & $177.92(5)$ & $177.74(6)$ & $177.53(10)$ & $177.45(8)$ \\
N3-Fe1-N6 & $95.80(5)$ & $95.89(6)$ & $96.07(11)$ & $96.13(8)$ \\
N3-Fe1-N7 & $83.58(5)$ & $83.46(6)$ & $83.33(10)$ & $83.42(7)$ \\
N3-Fe1-N10 & $88.57(5)$ & $88.49(6)$ & $88.51(10)$ & $88.08(8)$ \\
N4-Fe1-N5 & $97.68(5)$ & $97.70(6)$ & $97.59(11)$ & $97.61(8)$ \\
N4-Fe1-N6 & $173.48(5)$ & $173.33(6)$ & $173.26(10)$ & $173.32(8)$ \\
N4-Fe1-N7 & $94.11(5)$ & $94.16(5)$ & $94.04(9)$ & $94.05(7)$ \\
N4-Fe1-N10 & $90.57(5)$ & $90.45(6)$ & $90.48(10)$ & $90.40(7)$ \\
N5-Fe1-N6 & $86.23(5)$ & $86.34(6)$ & $86.38(11)$ & $86.39(8)$ \\
N5-Fe1-N7 & $96.37(5)$ & $96.56(6)$ & $96.82(10)$ & $96.67(8)$ \\
N5-Fe1-N10 & $91.69(5)$ & $91.72(6)$ & $91.60(10)$ & $92.09(8)$ \\
N6-Fe1-N7 & $80.23(5)$ & $80.06(6)$ & $80.04(10)$ & $80.13(8)$ \\
N6-Fe1-N10 & $94.53(5)$ & $94.74(6)$ & $94.87(10)$ & $94.82(8)$ \\
N7-Fe1-N10 & $170.05(5)$ & $169.89(6)$ & $169.83(11)$ & $169.56(8)$ \\
$\Sigma$ & 61.89 & 62.83 & 63.27 & 63.90 \\
$\Theta$ & 93.47 & 95.21 & 96.77 & 95.69 \\
S(Oh) & 0.721 & 0.742 & 0.747 & 0.753 \\
Octahedral volume $\left(\AA^{3}\right)$ & 10.291 & 10.320 & 10.358 & 10.389 \\
& & & &
\end{tabular}

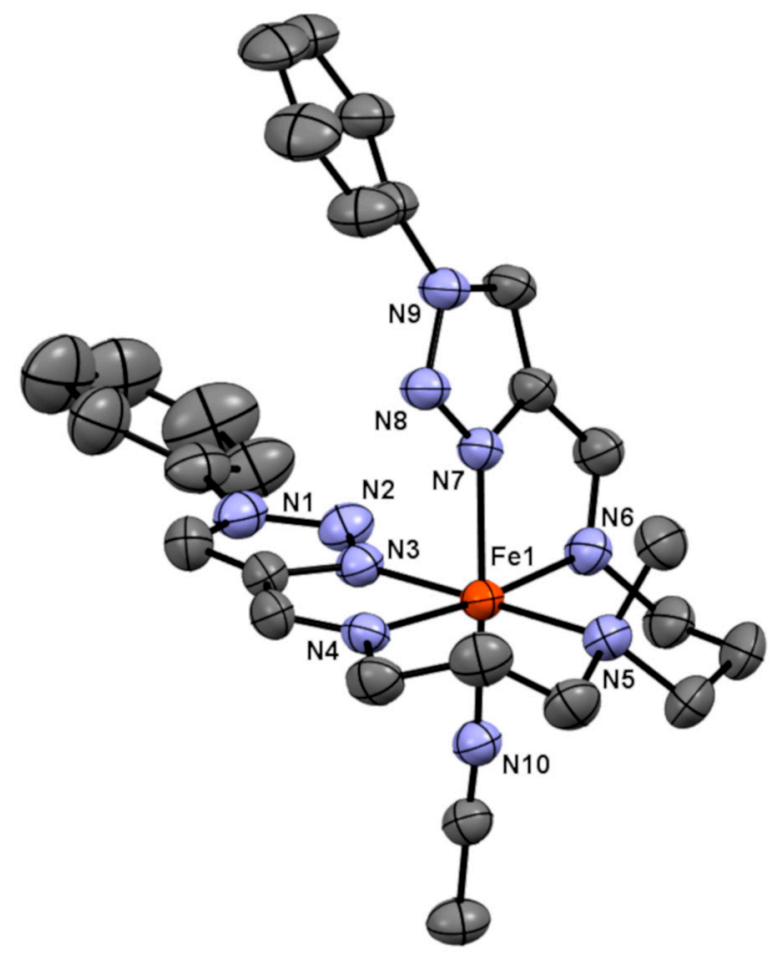

Figure 3. ORTEP drawing of the complex-cation $\left[\mathrm{Fe}^{\mathrm{II}} \mathrm{MeCN}\left(\mathrm{L}_{3-\mathrm{Me}-3}{ }^{\mathrm{Ph}}\right)\right]^{2+}$ of $\mathbf{1}$ at $296 \mathrm{~K}$ with the atom numbering scheme except for carbon and hydrogen atoms. The thermal ellipsoids are drawn with a $50 \%$ probability level. Hydrogen atoms have been omitted for clarity. 


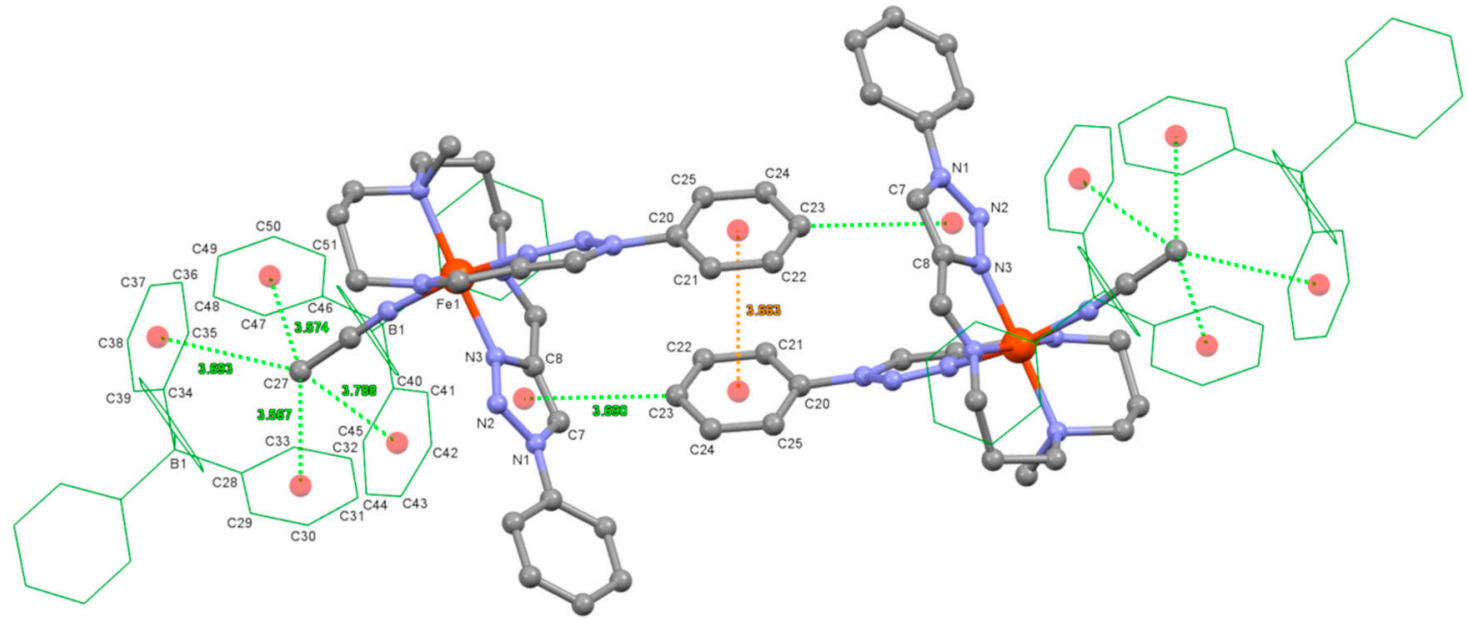

Figure 4. Representative intermolecular interactions of $\mathbf{1}$ at $296 \mathrm{~K}$. Complex-cations are shown as a ball and stick model. $\mathrm{B}(1) \mathrm{Ph}_{4}{ }^{-}$ions are indicated as green wireframe. Centroids of aromatic rings are described as transparent-red balls. $\pi-\pi$ (orange) and $\mathrm{CH} \cdots \pi$ (light green) interactions are indicated as dotted lines. The MeCN ligand is surrounded by four nearest phenyl rings of two $\mathrm{B}(1) \mathrm{Ph}_{4}{ }^{-}$ions via $\mathrm{CH} \cdots \pi$ interactions. Two neighboring complex-cations are connected by a P4AE interaction, forming a dimeric structure. Hydrogen atoms have been omitted for clarity.

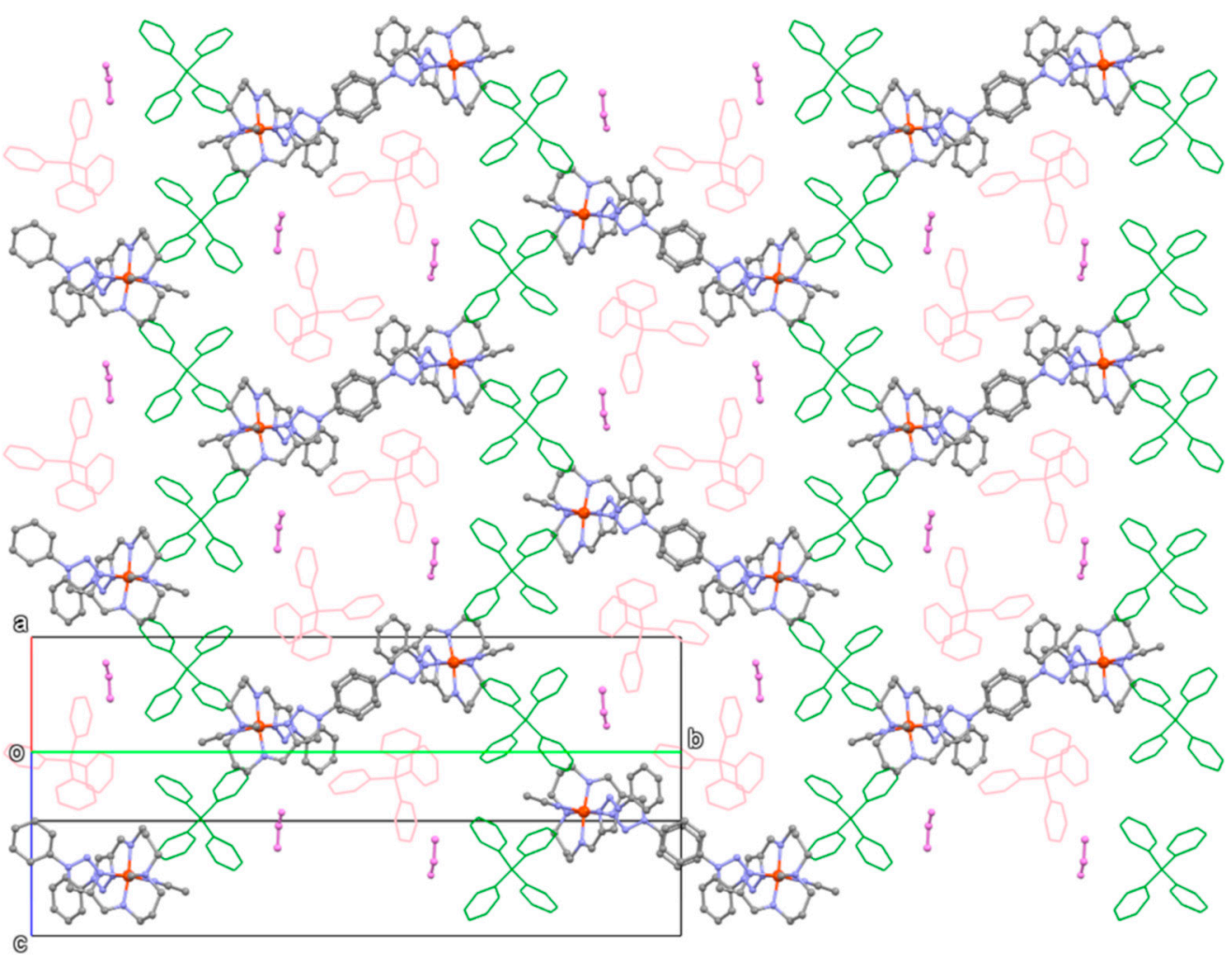

Figure 5. 2D layered structure of 1 at 296 K. Complex-cations and MeCN lattice solvents (violet) are shown as a ball and stick model. $\mathrm{B}(1) \mathrm{Ph}_{4}{ }^{-}$(green) and $\mathrm{B}(2) \mathrm{Ph}_{4}{ }^{-}$(pink) ions are indicated as wireframe. $\mathrm{CH} \cdots \pi$ interactions connect complex-cations and $\mathrm{B}(1) \mathrm{Ph}_{4}{ }^{-}$ions alternately into a $1 \mathrm{D}$ chain (longitudinal direction). The 1D chains are further connected by P4AE interactions between two neighboring complex-cations (transverse direction), forming 2D extended structure. $\mathrm{B}(2) \mathrm{Ph}_{4}{ }^{-}$ions and $\mathrm{MeCN}$ lattice solvents exist in the spaces of the 2D layer. Hydrogen atoms have been omitted for clarity. 


\subsection{DFT Calculations}

To explore the origin of the higher spin transition temperature of the 1,2,3-triazole-containing complex 1 than the imidazole-containing complex 2, we performed DFT calculations. It should be noted here that only the experimental crystal structure data are available for LS $\mathbf{1}$ (vide supra) and for 2 corresponding to the mixture of HS and LS species at $296 \mathrm{~K}$ [59].

First, we performed DFT calculations to estimate HS-LS energy differences $(\Delta E)$ at the experimental geometry (Table S1). Reflecting the spin state of the experimental crystal structures, large positive $\Delta E$ value $\left(168.3 \mathrm{~kJ} \mathrm{~mol}^{-1}\right)$ and small $\Delta E$ values $\left(45.5 \mathrm{~kJ} \mathrm{~mol}^{-1}\right.$ and $\left.-13.3 \mathrm{~kJ} \mathrm{~mol}^{-1}\right)$ were observed for $\mathbf{1}$ and 2 , respectively.

Next, we performed DFT geometry optimizations for both complexes in gas-phase. For the LS state of 1, the structural parameters of DFT optimized structure indicated reasonable agreement with the crystal structure data of LS phase at $296 \mathrm{~K}$ (See, Table 2 and Table S2). Although the structural features (average Fe-N length, $\Sigma, \Theta, S(\mathrm{Oh})$, and octahedral volume) of the DFT optimized LS 1 and $\mathbf{2}$ are similar to each other, the $\mathrm{Fe}-\mathrm{N}$ (triazole) distances in $\mathbf{1}$ are shorter than the $\mathrm{Fe}-\mathrm{N}$ (imidazole) distances in 2 by $0.05-0.07 \AA$. It should be mentioned here that the same tendency was observed in the comparison of the experimental crystal structures of the LS complex with the 1,2,3-triazole-containing linear hexadentate ligand and that of the imidazole-containing one [18]. Therefore, it can be speculated that 1,2,3-triazole-containing ligands form a stronger ligand field compared to imidazole-containing ones. For the HS state, the DFT optimized geometries of $\mathbf{1}$ and $\mathbf{2}$ are very similar to each other (Table S2). In addition, the structural parameters (average $\mathrm{Fe}-\mathrm{N}$ distance, $\Sigma, \Theta, \mathrm{S}(\mathrm{Oh})$, and octahedral volume) of the DFT optimized HS $\mathbf{1}$ and $\mathbf{2}$ are also similar to those in the experimental geometry of HS phase of similar imidazole-containing $\mathrm{Fe}^{\mathrm{II}}$ complexes [60], while the monodentate ligand of them are different from 1 and 2 (average Fe-N distance, $\Sigma, \Theta, S(\mathrm{Oh}$ ), and octahedral volume at $296 \mathrm{~K}$ are $=2.194 \AA$, 98.8, 187.1, 1.983, and 13.405 for NCS complex, and $2.198 \AA, 99.3,185.9,1.986$, and 13.474 for NCSe complex, respectively).

We also calculated $\Delta E$ values at the DFT optimized geometries to compare the strength of the ligand field of $\mathbf{1}$ and $\mathbf{2}$. As shown in Table S3, the large positive $\Delta E$ values are found in LS geometry of both $\mathbf{1}$ and 2 . The $\Delta E$ value of $\mathbf{1}$ is $28.5 \mathrm{~kJ} \mathrm{~mol}^{-1}$ larger than 2 , which implies that the strength of the ligand field is stronger in $\mathbf{1}$ rather than in $\mathbf{2}$, as expected from the aforementioned structural features.

We also performed DFT geometry optimizations for model complexes $\mathbf{1}^{\prime}$ and $\mathbf{2}^{\prime}$, in which two Ph groups in $\mathbf{1}$ and two Me groups in $\mathbf{2}$ were replaced by hydrogen atom to estimate the strength of the ligand field, excluding $\pi$ effects of the Ph ring and the steric effect of Me groups. The structural parameters of the DFT optimized structure are listed in Table S4. The structural parameters in $\mathbf{1}^{\prime}$ were hardly affected by excluding Ph groups in 1, which implies that the $\pi$ effects of the Ph ring are negligibly small, while the structural parameters in $2^{\prime}$ were slightly affected by excluding Me groups in 2. It is worth mentioning that $\mathrm{Fe}-\mathrm{N}$ (triazole) distances in $\mathbf{1}^{\prime}$ are still shorter than the Fe-N(imidazole) ones in $\mathbf{2}^{\prime}$ by $0.03 \AA$. Table S3 shows that the replacement of Ph groups in $\mathbf{1}$ also hardly affected the calculated $\Delta E$ value, and the $\Delta E$ value of $\mathbf{1}^{\prime}\left(149.3 \mathrm{~kJ} \mathrm{~mol}^{-1}\right)$ is also still larger than $\mathbf{2}^{\prime}\left(131.9 \mathrm{~kJ} \mathrm{~mol}^{-1}\right)$. These results demonstrated that the ligand field is stronger in the triazole-containing complex rather than in the imidazole-containing one, even if the $\pi$ effects of Ph rings and steric effect of Me groups were excluded.

From the above results, our DFT calculations elucidated that 1,2,3-triazole-containing ligands form the stronger ligand field compared to imidazole-containing ligands even for linear pentadentate ligand system, inducing the shift of the spin transition temperature from the lower temperature region in the imidazole-based complex to the higher region in the 1,2,3-triazole-based complex. 


\section{Conclusions}

In conclusion, here we have expanded our 1,2,3-triazole-containing polydentate ligand iron(II) SCO family into a linear pentadentate ligand system. The newly synthesized complex 1 shows an abrupt and incomplete HT SCO at around $400 \mathrm{~K}$ while the spin transition is irreversible due to the crystal-to-amorphous transformation associated with the loss of the lattice MeCN solvent. Although the cooperativity through the molecular assembly for SCO profile of $\mathbf{1}$ was not directly compared to that of the imidazole-containing analogue $\mathbf{2}$, the spin transition of $\mathbf{1}$ occurred more abruptly in the higher temperature region above RT than that of 2 . The 2D supramolecular structure based on the multiple $\mathrm{CH} \cdots \pi$ interactions between $\mathrm{MeCN}$ ligand and two $\mathrm{B}(1) \mathrm{Ph}_{4}{ }^{-}$ions, and $\mathrm{P} 4 \mathrm{AE}$ interactions between two neighboring complex-cations of $\mathbf{1}$ may have an important role for the emergence of cooperativity in the crystal lattice. DFT optimized HS and LS structures in the gas-phase of 1,2,3-triazole-containing system were compared to those of related imidazole-containing systems for the first time based on the experimental crystal structures of $\mathbf{1}$ (LS state) and $\mathbf{2}$ (mixture of LS and HS states), demonstrating that the 1,2,3-triazole-containing ligand $\mathrm{L}_{3-\mathrm{Me}-3}{ }^{\mathrm{Ph}}$ generates a stronger ligand field around the $\mathrm{N}_{6}$ octahedral iron(II) core than its imidazole analogue ligand $\mathrm{H}_{2} \mathrm{~L}^{2 \mathrm{Me}}$. Syntheses of analogues of $\mathbf{1}$ with different axial ligands are currently underway for the construction of the spectrochemical series and for fine tuning of $T_{1 / 2}$ of the present 1,2,3-triazole-based pentadentate ligand system.

Supplementary Materials: The following are available online at http://www.mdpi.com/2073-4352/9/6/276/s1, Figure S1: PXRD patterns of $\mathbf{1}$ at RT in different states: simulated from the single crystal X-ray data at $296 \mathrm{~K}$; as-synthesized; after SQUID measurements, Figure S2: IR spectra (KBr) for $\mathbf{1}$ at RT in different states: as-synthesized; after SQUID measurements, Table S1: HS-LS energy differences of $\mathbf{1}$ and $\mathbf{2}$ for Experimental geometry, Table S2: Relevant coordination bond lengths $(\AA)$ and structural parameters in DFT optimized structures for $\mathbf{1}$ and 2 , Table S3: HS-LS energy differences of 1, 2, $\mathbf{1}^{\prime}$, and $\mathbf{2}^{\prime}$ for DFT optimized geometry (LS), Table S4: Relevant coordination bond lengths $(\AA)$ and structural parameters in DFT optimized structures for model complexes $\mathbf{1}^{\prime}$ and

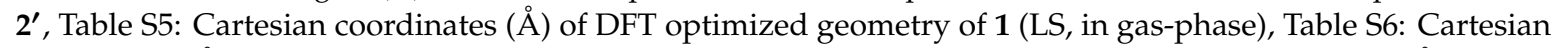
coordinates $(\AA)$ of DFT optimized geometry of $\mathbf{1}$ (HS, in gas-phase), Table S7: Cartesian coordinates (Å) of DFT optimized geometry of $\mathbf{2}$ (LS, in gas-phase), Table S8: Cartesian coordinates ( $\mathrm{A}$ ) of DFT optimized geometry of 2 (HS, in gas-phase), Figure S3: DFT optimized structures of LS 1 (a), HS 1 (b), LS 2 (c), and HS 2 (d) in gas-phase.

Author Contributions: Conceptualization, H.H.; Methodology, H.H. and T.U.; validation, T.M., H.H., and T.U.; formal analysis, H.H. and T.U.; investigation, T.M., K.N., and H.H.; resources, H.H. and T.U.; data curation, H.H. and T.U.; writing—original draft preparation, H.H. and T.U.; writing—review and editing, H.H. and T.U.; visualization, H.H.; supervision, H.H.; project administration, H.H.

Funding: This work was supported in part by JSPS KAKENHI Grant numbers JP18K14240 (to H.H.) and JP18K05028 (to T.U.).

Acknowledgments: A part of this work was conducted in Institute for Molecular Science, supported by Nanotechnology Platform Program (Molecule and Material Synthesis) of the Ministry of Education, Culture, Sports, Science and Technology (MEXT), Japan.

Conflicts of Interest: The authors declare no conflict of interest.

\section{References}

1. Gütlich, P.; Goodwin, H.A. (Eds.) Spin Crossover in Transition Metal Compounds I-III; Topics in Current Chemistry; Springer: Berlin, Germany, 2004; Volumes 233-235.

2. Halcrow, M.A. (Ed.) Spin-Crossover Materials-Properties and Applications; John Wiley \& Sons: Chichester, UK, 2013.

3. Gütlich, P.; Gaspar, A.B.; Garcia, Y. Spin state switching in iron coordination compounds. Beilstein J. Org. Chem. 2013, 9, 342-391. [CrossRef] [PubMed]

4. Linares, J.; Codjovi, E.; Garcia, Y. Pressure and Temperature Spin Crossover Sensors with Optical Detection. Sensors 2012, 12, 4479-4492. [CrossRef] [PubMed]

5. Gentili, D.; Demitri, N.; Schäfer, B.; Liscio, F.; Bergenti, I.; Ruani, G.; Ruben, M.; Cavallini, M. Multi-modal sensing in spin crossover compounds. J. Mater. Chem. C 2015, 3, 7836-7844. [CrossRef]

6. Halcrow, M.A. Spin-crossover Compounds with Wide Thermal Hysteresis. Chem. Lett. 2014, 43, 1178-1188. [CrossRef] 
7. Brooker, S. Spin crossover with thermal hysteresis: Practicalities and lessons learnt. Chem. Soc. Rev. 2015, 44, 2880-2892. [CrossRef] [PubMed]

8. Matsumoto, T.; Newton, G.N.; Shiga, T.; Hayami, S.; Matsui, Y.; Okamoto, H.; Kumai, R.; Murakami, Y.; Oshio, H. Programmable spin-state switching in a mixed-valence spin-crossover iron grid. Nat. Commun. 2014, 5, 1-8. [CrossRef] [PubMed]

9. Li, Z.-Y.; Ohtsu, H.; Kojima, T.; Dai, J.-W.; Yoshida, T.; Breedlove, B.K.; Zhang, W.-X.; Iguchi, H.; Sato, O.; Kawano, M.; et al. Direct Observation of Ordered High-Spin-Low-Spin Intermediate States of an Iron(III) Three-Step Spin-Crossover Complex. Angew. Chem. Int. Ed. 2016, 55, 5184-5189. [CrossRef]

10. Murphy, M.J.; Zenere, K.A.; Ragon, F.; Southon, P.D.; Kepert, C.J.; Neville, S.M. Guest programmable multlstep spin crossover in a porous 2-D Hofmann-type material. J. Am. Chem. Soc. 2017, 139, 1330-1335. [CrossRef]

11. Zhang, D.; Trzop, E.; Valverde-Muñoz, F.J.; Piñeiro-López, L.; Muñoz, M.C.; Collet, E.; Real, J.A. Competing Phases Involving Spin-State and Ligand Structural Orderings in a Multistable Two-Dimensional Spin Crossover Coordination Polymer. Cryst. Growth Des. 2017, 17, 2736-2745. [CrossRef]

12. Bao, X.; Guo, P.-H.; Liu, W.; Tucek, J.; Zhang, W.-X.; Leng, J.-D.; Chen, X.-M.; Gural'skiy, I.; Salmon, L.; Bousseksou, A.; et al. Remarkably high-temperature spin transition exhibited by new 2D metal-organic frameworks. Chem. Sci. 2012, 3, 1629. [CrossRef]

13. Liu, W.; Bao, X.; Li, J.-Y.; Qin, Y.-L.; Chen, Y.-C.; Ni, Z.-P.; Tong, M.-L. High-Temperature Spin Crossover in Two Solvent-Free Coordination Polymers with Unusual High Thermal Stability. Inorg. Chem. 2015, 54, 3006-3011. [CrossRef]

14. Zheng, S.; Reintjens, N.R.M.; Siegler, M.A.; Roubeau, O.; Bouwman, E.; Rudavskyi, A.; Havenith, R.W.A.; Bonnet, S. Stabilization of the Low-Spin State in a Mononuclear Iron(II) Complex and High-Temperature Cooperative Spin Crossover Mediated by Hydrogen Bonding. Chem. A Eur. J. 2016, 22, 331-339. [CrossRef]

15. Hora, S.; Hagiwara, H. High-Temperature Wide Thermal Hysteresis of an Iron(II) Dinuclear Double Helicate. Inorganics 2017, 5, 49. [CrossRef]

16. Craze, A.R.; Howard-Smith, K.J.; Bhadbhade, M.M.; Mustonen, O.; Kepert, C.J.; Marjo, C.E.; Li, F. Investigation of the High-Temperature Spin-Transition of a Mononuclear Iron(II) Complex Using X-ray Photoelectron Spectroscopy. Inorg. Chem. 2018, 57, 6503-6510. [CrossRef] [PubMed]

17. Takahashi, K.; Yamamoto, K.; Yamamoto, T.; Einaga, Y.; Shiota, Y.; Yoshizawa, K.; Mori, H. High-Temperature Cooperative Spin Crossover Transitions and Single-Crystal Reflection Spectra of $\left[\mathrm{Fe}{ }^{\mathrm{III}}\left(\mathrm{qsal}_{2}\right]\left(\mathrm{CH}_{3} \mathrm{OSO}_{3}\right)\right.$ and Related Compounds. Crystals 2019, 9, 81. [CrossRef]

18. Hagiwara, H. High-temperature Spin Crossover of a Solvent-Free Iron(II) Complex with the Linear Hexadentate Ligand $\left[\mathrm{Fe}\left(\mathrm{L}_{2-3-2}{ }^{\mathrm{Ph}}\right)\right]\left(\mathrm{AsF}_{6}\right)_{2}\left(\mathrm{~L}_{2-3-2} \mathrm{Ph}=\right.$ bis[N-(1-Phenyl-1H-1,2,3-triazol-4-yl)methylidene-2aminoethyl]-1,3- propanediamine). Magnetochemistry 2019, 5, 10. [CrossRef]

19. Weber, B.; Bauer, W.; Obel, J. An iron(II) spin-crossover complex with a $70 \mathrm{~K}$ wide thermal hysteresis loop. Angew. Chem. Int. Ed. 2008, 47, 10098-10101. [CrossRef]

20. Hayami, S.; Gu, Z.Z.; Yoshiki, H.; Fujishima, A.; Sato, O. Iron(III) spin-crossover compounds with a wide apparent thermal hysteresis around room temperature. J. Am. Chem. Soc. 2001, 123, 11644-11650. [CrossRef] [PubMed]

21. Kahn, O.; Martinez, C.J. Spin-transition polymers: From molecular materials toward memory devices. Science 1998, 279, 44-48. [CrossRef]

22. Southon, P.D.; Liu, L.; Fellows, E.A.; Price, D.J.; Halder, G.J.; Chapman, K.W.; Moubaraki, B.; Murray, K.S.; Létard, J.F.; Kepert, C.J. Dynamic interplay between spin-crossover and host-guest function in a nanoporous metal-organic framework material. J. Am. Chem. Soc. 2009, 131, 10998-11009. [CrossRef]

23. Arcis-Castíllo, Z.; Zheng, S.; Siegler, M.A.; Roubeau, O.; Bedoui, S.; Bonnet, S. Tuning the transition temperature and cooperativity of bapbpy-based mononuclear spin-crossover compounds: Interplay between molecular and crystal engineering. Chem. A Eur. J. 2011, 17, 14826-14836. [CrossRef] [PubMed]

24. Zhao, X.-H.; Zhang, S.-L.; Shao, D.; Wang, X.-Y. Spin Crossover in $\left[\mathrm{Fe}(2-P i c o l y l a m i n e)_{3}\right]^{2+}$ Adjusted by Organosulfonate Anions. Inorg. Chem. 2015, 54, 7857-7867. [CrossRef] [PubMed]

25. Kershaw Cook, L.J.; Kulmaczewski, R.; Mohammed, R.; Dudley, S.; Barrett, S.A.; Little, M.A.; Deeth, R.J.; Halcrow, M.A. A Unified Treatment of the Relationship between Ligand Substituents and Spin State in a Family of Iron(II) Complexes. Angew. Chem. Int. Ed. 2016, 55, 4327-4331. [CrossRef] 
26. Hagiwara, H.; Masuda, T.; Ohno, T.; Suzuki, M.; Udagawa, T.; Murai, K.I. Neutral Molecular Iron(II) Complexes Showing Tunable Bistability at Above, Below, and Just Room Temperature by a Crystal Engineering Approach: Ligand Mobility into a Three-Dimensional Flexible Supramolecular Network. Cryst. Growth Des. 2017, 17, 6006-6019. [CrossRef]

27. Nakanishi, T.; Okazawa, A.; Sato, O. Halogen Substituent Effect on the Spin-Transition Temperature in Spin-Crossover Fe(III) Compounds Bearing Salicylaldehyde 2-Pyridyl Hydrazone-Type Ligands and Dicarboxylic Acids. Inorganics 2017, 5, 53. [CrossRef]

28. Phonsri, W.; Macedo, D.S.; Vignesh, K.R.; Rajaraman, G.; Davies, C.G.; Jameson, G.N.L.; Moubaraki, B.; Ward, J.S.; Kruger, P.E.; Chastanet, G.; et al. Halogen Substitution Effects on $\mathrm{N}_{2} \mathrm{O}$ Schiff Base Ligands in Unprecedented Abrupt $\mathrm{Fe}^{\mathrm{II}}$ Spin Crossover Complexes. Chem. A Eur. J. 2017, 23, 7052-7065. [CrossRef] [PubMed]

29. Kimura, A.; Ishida, T. Spin-Crossover Temperature Predictable from DFT Calculation for Iron(II) Complexes with 4-Substituted Pybox and Related Heteroaromatic Ligands. ACS Omega 2018, 3, 6737-6747. [CrossRef]

30. Nemec, I.; Herchel, R.; Boča, R.; Trávníček, Z.; Svoboda, I.; Fuess, H.; Linert, W. Tuning of spin crossover behaviour in iron(III) complexes involving pentadentate Schiff bases and pseudohalides. Dalton Trans. 2011, 40, 10090-10099. [CrossRef]

31. Tsuchida, R. Absorption Spectra of Co-ordination Compounds. Bull. Chem. Soc. Jpn. 1938, 13, 388-400. [CrossRef]

32. Shimura, Y. A Quantitative Scale of the Spectrochemical Series for the Mixed Ligand Complexes of $d^{6}$ Metals. Bull. Chem. Soc. Jpn. 1988, 61, 693-698. [CrossRef]

33. Ohta, S.; Yoshimura, C.; Matsumoto, N.; Okawa, H.; Ohyoshi, A. The Synthesis, Magnetic, and Spectroscopic Properties of Binuclear Iron(III) Complexes Bridged by Pyrazine, 1,1'-Tetramethylenebis(imidazol), or Bis(pyridine) Compounds Exhibiting a Spin-Equilibrium Behavior. Bull. Chem. Soc. Jpn. 1986, 59, 155-159. [CrossRef]

34. Hayami, S.; Inoue, K.; Osaki, S.; Maeda, Y. Synthesis and Magnetic Properties of Binuclear Iron(III) Complexes Containing Photoisomerization Ligand. Chem. Lett. 1998, 27, 987-988. [CrossRef]

35. Spiccia, L.; Fallon, G.D.; Grannas, M.J.; Nichols, P.J.; Tiekink, E.R.T. Synthesis and characterisation of mononuclear and binuclear iron(II) complexes of pentadentate and bis(pentadentate) ligands derived from 1,4,7-triazacyclononane. Inorg. Chim. Acta 1998, 279, 192-199. [CrossRef]

36. Boča, R.; Fukuda, Y.; Gembický, M.; Herchel, R.; Jaroščiak, R.; Linert, W.; Renz, F.; Yuzurihara, J. Spin crossover in mononuclear and binuclear iron(III) complexes with pentadentate Schiff-base ligands. Chem. Phys. Lett. 2000, 325, 411-419. [CrossRef]

37. Hayami, S.; Hosokoshi, Y.; Inoue, K.; Einaga, Y.; Sato, O.; Maeda, Y. Pressure-Stabilized Low-Spin State for Binuclear Iron(III) Spin-Crossover Compounds. Bull. Chem. Soc. Jpn. 2001, 74, 2361-2368. [CrossRef]

38. Kitashima, R.; Imatomi, S.; Yamada, M.; Matsumoto, N.; Maeda, Y. Gradual Two-step Spin Crossover Behavior of Binuclear Iron(III) Complex Bridged by trans -1,2-Bis(4-pyridyl)ethylene. Chem. Lett. 2005, 34, 1388-1389. [CrossRef]

39. Šalitroš, I.; Boča, R.; Dlháň, L.; Gembický, M.; Kožǐšek, J.; Linares, J.; Moncol, J.; Nemec, I.; Perašínová, L.; Renz, F.; et al. Unconventional spin crossover in dinuclear and trinuclear iron(III) complexes with cyanido and metallacyanido bridges. Eur. J. Inorg. Chem. 2009, 3141-3154. [CrossRef]

40. Nemec, I.; Boča, R.; Herchel, R.; Trávníček, Z.; Gembický, M.; Linert, W. Dinuclear Fe(III) complexes with spin crossover. Monatsh. Chem. 2009, 140, 815-828. [CrossRef]

41. Djukic, B.; Poddutoori, P.K.; Dube, P.A.; Seda, T.; Jenkins, H.A.; Lemaire, M.T. Bimetallic Iron(3+) Spin-Crossover Complexes Containing a 2,2'-Bithienyl Bridging bis-QsalH Ligand. Inorg. Chem. 2009, 48, 6109-6116. [CrossRef]

42. Fujinami, T.; Nishi, K.; Kitashima, R.; Murakami, K.; Matsumoto, N.; Iijima, S.; Toriumi, K. One-step and two-step spin crossover binuclear iron(III) complexes bridged by 4,4'-bipyridine. Inorg. Chim. Acta 2011, 376, 136-143. [CrossRef]

43. Boča, R.; Nemec, I.; Šalitroš, I.; Pavlik, J.; Herchel, R.; Renz, F. Interplay between spin crossover and exchange interaction in iron(III) complexes. Pure Appl. Chem. 2009, 81, 1357-1383. [CrossRef]

44. Herchel, R.; Boča, R.; Gembický, M.; Kožíšek, J.; Renz, F. Spin Crossover in a Tetranuclear Cr(III)-Fe(III) 3 Complex. Inorg. Chem. 2004, 43, 4103-4105. [CrossRef] [PubMed] 
45. Renz, F.; Jung, S.; Klein, M.; Menzel, M.; Thünemann, A.F. Molecular switching complexes with iron and tin as central atom. Polyhedron 2009, 28, 1818-1821. [CrossRef]

46. Gembický, M.; Boča, R.; Renz, F. A heptanuclear Fe(II)-Fe(III) 6 system with twelve unpaired electrons. Inorg. Chem. Commun. 2000, 3, 662-665. [CrossRef]

47. Boča, R.; Šalitroš, I.; Kožíšek, J.; Linares, J.; Moncol', J.; Renz, F. Spin crossover in a heptanuclear mixed-valence iron complex. Dalton Trans. 2010, 39, 2198-2200. [CrossRef]

48. Renz, F.; Kerep, P. Unprecedented multiple electronic spin transition in hepta- and nonanuclear complex compounds observed by Mössbauer spectroscopy. Polyhedron 2005, 24, 2849-2851. [CrossRef]

49. Renz, F.; Hill, D.; Klein, M.; Hefner, J. Unprecedented multistability in dodecanuclear complex compound observed by Mössbauer spectroscopy. Polyhedron 2007, 26, 2325-2329. [CrossRef]

50. Ohyoshi, A.; Honbo, J.; Matsumoto, N.; Ohta, S.; Sakamoto, S. Spin-Equilibrium Behavior in Solution of an Iron(III) Complex [Bis[3-(3-methoxysalicylideneamine)propyl]amino- $O, N, N^{\prime}, N^{\prime \prime}, O^{\prime}$ ](pyridine)iron(III) Tetraphenylborate. Bull. Chem. Soc. Jpn. 1986, 59, 1611-1613. [CrossRef]

51. Maeda, Y.; Noda, Y.; Oshio, H.; Takashima, Y. ${ }^{57}$ Fe Mössbauer Spectra, Crystal Structure, and Spin-Crossover Behavior of [Fe(mbpN)(lut)]BPh 4 . Bull. Chem. Soc. Jpn. 1992, 65, 1825-1831. [CrossRef]

52. Hirose, S.; Hayami, S.; Maeda, Y. Magnetic Properties of Iron(III) Complexes with Photoisomerizable Ligands. Bull. Chem. Soc. Jpn. 2000, 73, 2059-2066. [CrossRef]

53. Tanimura, K.; Kitashima, R.; Bréfuel, N.; Nakamura, M.; Matsumoto, N.; Shova, S.; Tuchagues, J.P. Infinite chain structure and steep spin crossover of a Fe ${ }^{\mathrm{III}}$ complex with a $\mathrm{N}_{3} \mathrm{O}_{2}$ pentadentate schiff-base ligand and 4-aminopyridine. Bull. Chem. Soc. Jpn. 2005, 78, 1279-1282. [CrossRef]

54. Bannwarth, A.; Schmidt, S.O.; Peters, G.; Sönnichsen, F.D.; Thimm, W.; Herges, R.; Tuczek, F. Fe ${ }^{\mathrm{III}}$ spin-crossover complexes with photoisomerizable ligands: Experimental and theoretical studies on the ligand-driven light-induced spin change effect. Eur. J. Inorg. Chem. 2012, 2776-2783. [CrossRef]

55. Herchel, R.; Trávníček, Z. 5-Aminotetrazole induces spin crossover in iron(III) pentadentate Schiff base complexes: Experimental and theoretical investigations. Dalton Trans. 2013, 42, 16279-16288. [CrossRef] [PubMed]

56. Krüger, C.; Augustín, P.; Nemec, I.; Trávníček, Z.; Oshio, H.; Boča, R.; Renz, F. Spin crossover in iron(III) complexes with pentadentate schiff base ligands and pseudohalido coligands. Eur. J. Inorg. Chem. 2013, 902-915. [CrossRef]

57. Krüger, C.; Augustín, P.; Dlháň, L.; Pavlik, J.; Moncol', J.; Nemec, I.; Boča, R.; Renz, F. Iron(III) complexes with pentadentate Schiff-base ligands: Influence of crystal packing change and pseudohalido coligand variations on spin crossover. Polyhedron 2015, 87, 194-201. [CrossRef]

58. Halcrow, M.A. The spin-states and spin-transitions of mononuclear iron(II) complexes of nitrogen-donor ligands. Polyhedron 2007, 26, 3523-3576. [CrossRef]

59. Nishi, K.; Fujinami, T.; Kitabayashi, A.; Matsumoto, N. Tetrameric spin crossover iron(II) complex constructed by imidazole $\cdots$ chloride hydrogen bonds. Inorg. Chem. Commun. 2011, 14, 1073-1076. [CrossRef]

60. Murakami, K.; Kitabayashi, A.; Yamauchi, S.; Nishi, K.; Fujinami, T.; Matsumoto, N.; Iijima, S.; Kojima, M. Iron(II) complexes with a linear pentadentate ligand $\mathrm{H}_{2} \mathrm{~L}^{1}=\operatorname{bis}\left(N, N^{\prime}-2-\right.$ methylimidazol-4-ylmethylideneaminopropyl)methylamine and a monodentate ligand $X\left(X=\mathrm{N}_{3}^{-}, \mathrm{NCS}^{-}, \mathrm{NCSe}^{-}\right)$. Inorg. Chim. Acta 2013, 400, 244-249. [CrossRef]

61. Hagiwara, H.; Tanaka, T.; Hora, S. Synthesis, structure, and spin crossover above room temperature of a mononuclear and related dinuclear double helicate iron(II) complexes. Dalton Trans. 2016, 45, 17132-17140. [CrossRef]

62. Hagiwara, H.; Okada, S. A polymorphism-dependent $T_{1 / 2}$ shift of $100 \mathrm{~K}$ in a hysteretic spin-crossover complex related to differences in intermolecular weak $\mathrm{CH} \cdots \mathrm{X}$ hydrogen bonds $(\mathrm{X}=\mathrm{S}$ vs. $\mathrm{S}$ and $\mathrm{N})$. Chem. Commun. 2016, 52, 815-818. [CrossRef]

63. Hagiwara, H.; Minoura, R.; Okada, S.; Sunatsuki, Y. Synthesis, Structure, and Magnetic Property of a New Mononuclear Iron(II) Spin Crossover Complex with a Tripodal Ligand Containing Three 1,2,3-Triazole Groups. Chem. Lett. 2014, 43, 950-952. [CrossRef]

64. Siddiki, A.A.; Takale, B.S.; Telvekar, V.N. One pot synthesis of aromatic azide using sodium nitrite and hydrazine hydrate. Tetrahedron Lett. 2013, 54, 1294-1297. [CrossRef]

65. Pathigoolla, A.; Pola, R.P.; Sureshan, K.M. A versatile solvent-free azide-alkyne click reaction catalyzed by in situ generated copper nanoparticles. Appl. Catal. A Gen. 2013, 453, 151-158. [CrossRef] 
66. L'abbé, G.; Bruynseels, M.; Delbeke, P.; Toppet, S. Molecular rearrangements of 4-iminomethyl-1,2,3-triazoles. Replacement of 1-aryl substituents in $1 \mathrm{H}$-1,2,3-triazole-4-carbaldehydes. J. Heterocycl. Chem. 1990, 27, 2021-2027. [CrossRef]

67. Kahn, O. Molecular Magnetism; VCH: Weinheim, Germany, 1993.

68. Bain, G.A.; Berry, J.F. Diamagnetic Corrections and Pascal's Constants. J. Chem. Educ. 2008, 85, 532. [CrossRef]

69. SCALE3 ABSPACK, version 1.0.4; gui: 1.03; An oxford diffraction program; Oxford Diffraction Ltd.: Abingdon, UK, 2005.

70. Rigaku Oxford Diffraction, CrysAlisPro Software system, version 1.171.39.46; Rigaku Corporation: Oxford, UK, 2018.

71. Sheldrick, G.M. SHELXT-Integrated space-group and crystal-structure determination. Acta Crystallogr. Sect. A Found. Adv. 2015, 71, 3-8. [CrossRef] [PubMed]

72. Sheldrick, G.M. Crystal structure refinement with SHELXL. Acta Crystallogr. Sect. C Struct. Chem. 2015, 71, 3-8. [CrossRef]

73. Dolomanov, O.V.; Bourhis, L.J.; Gildea, R.J.; Howard, J.A.K.; Puschmann, H. OLEX2: A complete structure solution, refinement and analysis program. J. Appl. Crystallogr. 2009, 42, 339-341. [CrossRef]

74. Llunell, M.; Casanova, D.; Cirera, J.; Alemany, P.; Alvarez, S. SHAPE2.1. Program for Calculating Continuous Shape Measures of Polyhedral Structures; Universitat de Barcelona: Barcelona, Spain, 2013.

75. Zhao, Y.; Truhlar, D.G. The M06 suite of density functionals for main group thermochemistry, thermochemical kinetics, noncovalent interactions, excited states, and transition elements: Two new functionals and systematic testing of four M06-class functionals and 12 other functionals. Theor. Chem. Acc. 2008, 120, 215-241. [CrossRef]

76. Frisch, M.J.; Trucks, G.W.; Schlegel, H.B.; Scuseria, G.E.; Robb, M.A.; Cheeseman, J.R.; Scalmani, G.; Barone, V.; Mennucci, B.; Petersson, G.A.; et al. Gaussian 09, Revision B.01, Gaussian, Inc.: Wallingford, CT, USA, 2010.

77. Nakamoto, K. Infrared and Raman Spectra of Inorganic and Coordination Compounds, 6th ed.; John Wiley \& Sons: Hoboken, NJ, USA, 2009.

78. Boča, R.; Baran, P.; Boča, M.; Dlháň, L.; Fuess, H.; Haase, W.; Linert, W.; Papánková, B.; Werner, R. Spin crossover in bis(2,6-bis(benzimidazol-2-yl)pyridine) iron(II) tetraphenylborate. Inorg. Chim. Acta 1998, 278, 190-196. [CrossRef]

79. Hagiwara, H.; Hashimoto, S.; Matsumoto, N.; Iijima, S. Two-Dimensional Iron(II) Spin Crossover Complex Constructed of Bifurcated $\mathrm{NH}_{\cdots} \cdot \mathrm{O}^{-}$Hydrogen Bonds and $\pi-\pi$ Interactions: $\left[\mathrm{Fe}^{\mathrm{II}}\left(\mathrm{HL}^{\mathrm{H}, \mathrm{Me}}\right)_{2}\right]\left(\mathrm{ClO}_{4}\right)_{2} \cdot 1.5 \mathrm{MeCN}$ $\left(\mathrm{HL}^{\mathrm{H}, \mathrm{Me}}=\right.$ Imidazol-4-yl-methylidene-8-amino-2-methylquinoline). Inorg. Chem. 2007, 46, 3136-3143. [CrossRef] [PubMed]

80. Costa, J.S.; Rodríguez-Jiménez, S.; Craig, G.A.; Barth, B.; Beavers, C.M.; Teat, S.J.; Aromí, G. Three-way crystal-to-crystal reversible transformation and controlled spin switching by a nonporous molecular material. J. Am. Chem. Soc. 2014, 136, 3869-3874. [CrossRef] [PubMed]

81. Yang, F.-L.; Chen, X.; Wu, W.-H.; Zhang, J.-H.; Zhao, X.-M.; Shi, Y.-H.; Shen, F. Spin switching in tris(8-aminoquinoline)iron(II)(BPh$)_{2}$ : Quantitative guest-losing dependent spin crossover properties and single-crystal-to-single-crystal transformation. Dalton Trans. 2018. [CrossRef] [PubMed]

82. Bushuev, M.B.; Vinogradova, K.A.; Gatilov, Y.V.; Korolkov, I.V.; Nikolaenkova, E.B.; Krivopalov, V.P. Spin crossover in iron(II) hexafluorophosphate complexes with 2-(pyridin-2-yl)-4-(3,5-di-R-1H-pyrazol-1yl)-6-methylpyrimidines. Inorg. Chim. Acta 2017, 467, 238-243. [CrossRef]

83. Craze, A.R.; Bhadbhade, M.M.; Kepert, C.J.; Lindoy, L.F.; Marjo, C.E.; Li, F. Solvent Effects on the Spin-Transition in a Series of Fe(II) Dinuclear Triple Helicate Compounds. Crystals 2018, 8, 376. [CrossRef]

84. Sertphon, D.; Harding, P.; Murray, K.S.; Moubaraki, B.; Neville, S.M.; Liu, L.; Telfer, S.G.; Harding, D.J. Solvent Effects on the Spin Crossover Properties of Iron(II) Imidazolylimine Complexes. Crystals 2019, 9, 116. [CrossRef]

85. Jornet-Mollá, V.; Giménez-Saiz, C.; Romero, F.M. Synthesis, Structure, and Photomagnetic Properties of a Hydrogen-Bonded Lattice of $\left[\mathrm{Fe}(\mathrm{bpp})_{2}\right]^{2+}$ Spin-Crossover Complexes and Nicotinate Anions. Crystals 2018, 8, 439. [CrossRef]

86. Guionneau, P.; Marchivie, M.; Bravic, G.; Létard, J.-F.; Chasseau, D. Structural aspects of spin crossover. Examples of the $\left[\mathrm{Fe}^{\mathrm{II}} \mathrm{L}_{n}(\mathrm{NCS})_{2}\right]$ complexes. Top. Curr. Chem. 2004, 234, 97-128.

87. Marchivie, M.; Guionneau, P.; Létard, J.-F.; Chasseau, D. Photo-induced spin-transition: The role of the iron(II) environment distortion. Acta Crystallogr. Sect. B 2005, 61, 25-28. [CrossRef] 
88. Spek, A.L. Structure validation in chemical crystallography. Acta Crystallogr. Sect. D Biol. Crystallogr. 2009, 65, 148-155. [CrossRef]

89. Russell, V.; Scudder, M.; Dance, I. The crystal supramolecularity of metal phenanthroline complexes. J. Chem. Soc. Dalton Trans. 2001, 0, 789-799. [CrossRef]

(c) (C) 2019 by the authors. Licensee MDPI, Basel, Switzerland. This article is an open access article distributed under the terms and conditions of the Creative Commons Attribution (CC BY) license (http://creativecommons.org/licenses/by/4.0/). 